\title{
Synthesis of Antioxidant Additive from Safflower Seed Oil
}

\author{
Marithiza G. Vieira, ${ }^{\oplus a}$ Lilian R. Batista, ${ }^{\oplus *, a}$ Aline S. Muniz, ${ }^{a}$ Juliana E. Lichston, ${ }^{b}$ \\ Angelo R. S. Oliveira, ${ }^{c}$ Maria A. F. César-Oliveira ${ }^{c}$ and Nelson R. Antoniosi Filho ${ }^{a}$ \\ ${ }^{a}$ Laboratório de Métodos de Extração e Separação (LAMES), Instituto de Química, \\ Universidade Federal de Goiás, 74001-970 Goiânia-GO, Brazil \\ ${ }^{b}$ Departamento de Botânica, Ecologia e Zoologia, Centro de Biociências, \\ Universidade Federal do Rio Grande do Norte, 59064-741 Natal-RN, Brazil \\ 'Laboratório de Química de Polímeros e Síntese Orgânica (LEQUIPE), Departamento de Química, \\ Universidade Federal do Paraná, 81531-980 Curitiba-PR, Brazil
}

\begin{abstract}
Several published studies have evaluated the problems associated with the utilization of biodiesel obtained from safflower (Carthamus tinctorius L.) oil due to the low oxidative stability, caused by the high content of unsaturated fatty acids. Thus, this study aimed at the extraction of safflower seed oil and its use as an unsaturation source to obtain a synthetic antioxidant. The synthesis of this phenolic additive was done by modifying its structure through the addition of hydroquinone to the unsaturation of the oil, by electrophilic substitution. It was investigated and confirmed that this reaction is promising for obtaining phenolic products, with high yields $(83.5 \%)$. The product obtained in this research was evaluated as an antioxidant in commercial biodiesel by the Rancimat method, using $5000 \mathrm{ppm}$ of the synthesized additive the induction period increased from 8 to $17 \mathrm{~h}$ ( 2.12 times). Therefore, this paper brought a positive response to the improvement of biodiesel oxidation stability that creates a possibility to increase the use and expansion of this fuel in the market, as utilization of the safflower seed as raw material for additives, bringing a new market for these seeds.
\end{abstract}

Keywords: biofuels, antioxidant additives, safflower seed oil, biodiesel

\section{Introduction}

Safflower (Carthamus tinctorius L.) is oilseed of the family Asteraceae and can be produced in arid or semiarid regions or where moderate salinity water is used for irrigation. Safflower is a raw material with great productive potential and several advantages such as resistance to high temperatures and semi-arid climates, as well as a short cultivation cycle of 110 to 160 days. ${ }^{1}$ Thus, safflower is a productive alternative for regions previously considered unfavorable for the cultivation of most conventional oilseeds. ${ }^{1,2}$ The oil content corresponds to 32 to $40 \%{ }^{3,4}$ may vary according to seed genotypes, growing conditions, and soil type..$^{4-6}$ Safflower yield potential can reach $3000 \mathrm{~kg} \mathrm{ha}^{-1}$, which is considerably higher than conventional oilseeds such as soybean. ${ }^{7}$ Several published studies ${ }^{4,711}$ have presented potential applications for safflower such as the production of biodiesel and bioactive food ingredient. A

*e-mail: lilianribeiro_18@hotmail.com more detailed approach to the potential applications of safflower can be found in the paper of Khalid et al. ${ }^{4}$ Several studies have addressed the viability of safflower biodiesel production..$^{2,10,12}$ Nonetheless, owing to the predominant presence of unsaturated fatty acids that can reach up to $90 \%$, safflower biodiesel has low oxidative stability. ${ }^{1,7}$ Unsaturations have a greater tendency to polymerization reactions forming higher molecular weight products, which increases fuel viscosity. ${ }^{13}$ The presence of degradation compounds can cause fouling and deposit formation in vehicle tanks, as well as the alteration of their combustion characteristics, considerably compromising the biodiesel quality. ${ }^{14}$

Oxidative stability of biodiesel is an important parameter, which can be defined as the ability of biofuel to resist physicochemical changes caused by interaction with heat, light, water, and oxygen. ${ }^{13,14}$ Such factors are responsible for autoxidation, photo-oxidation, thermal and enzymatic oxidation. ${ }^{15}$ The autoxidation is the most investigated oxidative process as it generates a greater 
number of oxidation products. ${ }^{13,16,17}$ Autoxidation occurs in three stages: initiation, propagation, and termination. In the initiation and propagation stages, where additives can act, free radical formation occurs, generating hydroperoxides. In the termination step aldehydes, carboxylic acids, hydrocarbons, ketones, and polymers are formed, the so-called secondary oxidation products. At this stage, the process is completely irreversible..$^{15,16,18,19}$ Thus, the addition of antioxidant additives is the best alternative to improve biodiesel stability. Antioxidants are compounds that act by delaying, controlling or inhibiting substrate autoxidation processes which reduce the formation of unwanted by-products. ${ }^{15,20}$

Antioxidants may be of natural origin (tocopherols, ascorbic acid, caffeic acid, resveratrol, and flavonoids) or from synthetic origin. ${ }^{20-22}$ In a recent study, Bharti et al. ${ }^{23}$ evaluated that green tea can improve the oxidative stability of biodiesel. However, a comparison with synthetic additives was not performed. In another research, de Sousa et al. ${ }^{20}$ assessed the antioxidant activity of curcumin, $\beta$-carotene for soybean biodiesel. Nevertheless, only curcumin showed adequate antioxidant activity for soybean biodiesel, increasing the induction period of biodiesel by $83 \% .^{20}$ Natural antioxidants are used to delay termination, although the most used are of synthetic origin, because synthetic additives have an antioxidant activity superior to natural additives..$^{24-26}$ Moreover, natural antioxidant additives are more sensitive to concentrations, and at higher concentrations, they offer pro-oxidant effects. ${ }^{15}$

In petroleum products are mainly utilized synthetic additives: butylated hydroxytoluene (BHT), butylated hydroxyanisole (BHA) and tert-butylhydroquinone (TBHQ). ${ }^{16,27-30}$ Such additives are phenolic type and are mostly used in the biodiesel industry, as they have a good performance and a low cost. ${ }^{15,31}$

Phenolic additives are responsible for donating hydrogen radicals to lipid radical avoiding chain reaction through the interception of peroxide radicals. Thus, preventing both the formation of hydroperoxides and other lipid radicals. ${ }^{32}$ However, these phenolic compounds have limited solubility in the biodiesel. ${ }^{13,15}$

In the study by Muniz-Wypych et al., ${ }^{13}$ a new class of antioxidant additives was developed from the addition of hydroquinone and catechol in unsaturated fatty acid esters. The synthesized additives significantly improved the stability of rapeseed biodiesel. The presence of hydroxyls in ortho-para positions facilitates donation of their protons that cause decrease to radical formation, as their propagation, giving a delay in the oxidation rate, and increased the induction period. Moreover, it was demonstrated that all synthesized additives were more soluble in biodiesel than hydroquinone and catechol, in the same molar concentrations. However, additives with the addition of hydroquinone showed better results than additives synthesized from the addition of catechol.

Thus, this research aimed at chemical modification in the structure of the safflower seed oil to synthesize the antioxidant compounds that increased phenol solubility in biodiesel. The hydroquinone was added to the $\mathrm{sp}^{2}$ carbon present in the safflower seed oil composition, thus can be obtained a homogeneous mixture with the biofuel that significantly improve the solubility. This paper aims to contribute with other studies that aim to add value to safflower raw material.

\section{Experimental}

\section{Oil characterization}

Safflower seeds were ground in an industrial blender to promote peel breakage. Subsequently, safflower seeds were dried in an oven at $80^{\circ} \mathrm{C}$ for $24 \mathrm{~h}$. Oil was extracted from dried and ground seeds in hexane for $6 \mathrm{~h}$ using a Soxhlet system. Subsequently, the solvent was removed by using a rotary evaporator.

The physicochemical characteristics of the lipid fraction of the oil from safflower seeds were determined by density tests at $20{ }^{\circ} \mathrm{C}$ (ABNT NBR 14065), ${ }^{33}$ kinematic viscosity (ABNT NBR 10441$)^{34}$ at 40 and $100^{\circ} \mathrm{C}$, oxidative stability (EN 14112), ${ }^{35}$ ASTM color (ABNT 14483), ${ }^{36}$ cloud point $\left(\right.$ ASTM D 2500) ${ }^{37}$ and pour point (ASTM D 97). ${ }^{38}$

The fatty acid composition of the oil was determined by Hartman and Lago method adapted to microscale. ${ }^{39}$ The phase analysis of fatty acid methyl esters was done by using Shimadzu, GC-17A gas chromatograph coupled to a Shimadzu QP5050A mass spectrometer. The capillary column used was DB-WAX $(30 \mathrm{~m} \times 0.25 \mathrm{~mm} \times 0.25 \mu \mathrm{m})$. The oven was set at $80{ }^{\circ} \mathrm{C}$, with a heating ramp from $10{ }^{\circ} \mathrm{C} \mathrm{min}-1$ to $250{ }^{\circ} \mathrm{C}$, remained at this temperature for $5 \mathrm{~min}$. The injector and interface temperature was $250^{\circ} \mathrm{C}$. The carrier gas used was helium 5.0, at a flow rate of $42.5 \mathrm{~cm} \mathrm{~s}^{-1}$. The split ratio was 1:30. The ionization mode was the electronic impact (EI) in the scan configuration with fragment monitoring ranging from 20 to 350 mass/charge.

\section{Chemical oil modification}

To obtain the antioxidant additive, $10 \mathrm{mmol}$ safflower seed oil was added to $40 \mathrm{mmol}$ hydroquinone (SigmaAldrich, St. Louis, USA) and $60 \mathrm{mmol}$ methanesulfonic acid (Sigma-Aldrich, St. Louis, USA) in a round bottom flask. The reaction mixture was placed under magnetic 
stirring under nitrogen atmosphere for $20 \mathrm{~h}$. Then, the product obtained was transfered to a $500 \mathrm{~mL}$ beaker with $50 \mathrm{~mL}$ chloroform (Neon, Suzano, Brazil) and washed 5 times with $100 \mathrm{~mL}$ water and brine. The organic phase was dried over anhydrous sodium sulfate (Êxodo Científica, Sumaré, Brazil) and evaporated by using a rotary evaporator. Thus, hydroquinone safflower seed oil (PSO) was obtained.

The product was characterized by Fourier transform infrared attenuated total reflection (FTIR-ATR) and nuclear magnetic resonance $\left({ }^{1} \mathrm{H}\right.$ NMR) techniques. The commercial biodiesel without antioxidants was used to test the antioxidant activity of PSO. The commercial biodiesel is a mixture of 70\% soybean biodiesel and 30\% beef tallow biodiesel. The PSO was added to biodiesel at concentrations of 250, 500, 1000, 2000, and $5000 \mathrm{ppm}$ (by weight).

\section{Results and Discussion}

\section{Oil characterization}

The safflower seeds presented an oil content of $29.0 \%$. Oil contents of safflower cultivars can be ranged from 23 to $36 \%,{ }^{4}$ depending on the genes and environment used. ${ }^{5}$ Conventional oilseeds such as soybean (15-20\%) and corn (up to $21 \%)^{7,40,41}$ has lower lipid content than safflower. Thus, safflower oil has a high productive potential.

Table 1 shows the results of the physicochemical characteristics of safflower seed oil. The results in this study are in agreement with the data found by Yesilyurt et al. ${ }^{7}$ The safflower seed oil has a density of $0.91 \mathrm{~g} \mathrm{~cm}^{-3}$ which is similar to other vegetable oils. ${ }^{42}$ The viscosity of vegetable oils ranges from 27.2 to $53.6 \mathrm{~mm}^{2} \mathrm{~s}^{-1}$, for safflower seed oil the result was within the expected range. Safflower seed oil showed low oxidative stability compared to other vegetable oils, due to the predominance of unsaturated fatty acids. Unsaturated fatty acid chains contain more reactive sites (unsaturations) and are particularly susceptible to free radical attack. ${ }^{43,44}$ However, the presence of unsaturated fatty acids results in a reduction of the pour point and cloud point for the oil, as shown in Table 1.

Determining the fatty acid profile makes it possible to know the oil applications for industrial, pharmaceutical, and nutritional applications. ${ }^{5}$ Safflower seed oil showed a predominance of unsaturated fatty acids, which corresponds to $84.7 \%$ of the total fatty acids, corroborating with the literature. ${ }^{7}$ Major unsaturated fatty acids are linoleic and oleic acid comprising 60.8 and $23.7 \%$ of total fatty acids, respectively. Moreover, the safflower seed oil has a higher polyunsaturation $(60.9 \%)$ level than in most conventional
Table 1. Characterization of safflower seed oil

\begin{tabular}{lcc}
\hline Property & This study & Yesilyurt et al. ${ }^{7}$ \\
\hline Density at $20{ }^{\circ} \mathrm{C} /\left(\mathrm{kg} \mathrm{m}^{-3}\right)$ & 919.19 & 921.0 \\
Color & 2.0 & $2.0-2.3$ \\
Viscosity at $40{ }^{\circ} \mathrm{C} /\left(\mathrm{mm}^{-2} \mathrm{~s}^{-1}\right)$ & 27.18 & $26.8-34.1$ \\
Viscosity at $100{ }^{\circ} \mathrm{C} /\left(\mathrm{mm}^{-2} \mathrm{~s}^{-1}\right)$ & 6.94 & 7.706 \\
Pour point $/{ }^{\circ} \mathrm{C}$ & -23.0 & $-22.0-(6.0)$ \\
Cloud point $/{ }^{\circ} \mathrm{C}$ & -14.0 & $-14.0-(6.0)$ \\
Oxidation stability / & 2.96 & - \\
\hline
\end{tabular}

oilseeds such as soybean, rapeseed, sunflower, and even unconventional seed oil such as cotton and jatropha. The saturated fatty acids are present in a lower proportion of $15.3 \%$ of total fatty acids, as shown in Table 2. Major saturated fatty acids are palmitic and stearic acids consisted of 10.3 and $4.2 \%$ content, respectively. The results in this study are in agreement with the data found by Yesilyurt et al. ${ }^{7}$

Table 2. Safflower seed oil fatty acid composition

\begin{tabular}{lcc}
\hline \multirow{2}{*}{ Fatty acid (structure) } & \multicolumn{2}{c}{ Percentage / \% } \\
\cline { 2 - 3 } & This study & Yesilyurt et al. $^{7}$ \\
\hline Myristic (C14:0) & 0.20 & 0.05 \\
Palmitic (C16:0) & 10.3 & $5.28-10.78$ \\
Palmitoleic (C16:1) & 0.1 & 0.05 \\
Stearic (C18:0) & 4.2 & $1.79-3.41$ \\
Oleic (C18:1) & 23.7 & $14.17-34.75$ \\
Linoleic (C18:2) & 60.8 & $21.04-73.87$ \\
Linolenic (C18:3) & 0.1 & $0.08-2.38$ \\
Arachidic (C20:0) & 0.6 & $0.372-1.69$ \\
\hline Saturated & 15.3 & $7.52-16.5$ \\
Monounsaturated & 23.8 & $14.17-37.85$ \\
Polyunsaturated & 60.9 & $50.22-74.24$ \\
\hline
\end{tabular}

Chemical modification of oil

The reaction condition for preparing the antioxidant additive was successful and the yield was $83.5 \%$. Hydroquinone (phenolic additive) has a high polarity, which makes its solubility difficult in biodiesel, even at low concentrations. ${ }^{13,17}$ Solubility is an important parameter because that ensures the uniform distribution of antioxidants in biodiesel resulting in increased antioxidant activity of the additive. The partially fat-soluble polar antioxidants such as pyrogallol, TBHQ, and propyl gallate showed to be more efficient in protecting biodiesel than the fat-soluble BHT and BHA antioxidants. ${ }^{15}$ Thus, the 
addition of hydroquinone to the triacylglyceride structure aims to improve the solubility of the phenolic additive. ${ }^{13}$

Figure 1 shows the infrared spectra of the PSO and from safflower seeds oil. It is possible to conclude that the insertion of hydroquinone in the safflower seed oil triacylglycerides occurred since the phenolic hydroxyls are present at $3418 \mathrm{~cm}^{-1}$. Moreover, it was observed an intense stretching $\mathrm{C}-\mathrm{H} \mathrm{sp}{ }^{3}$ from hydrocarbonic chains $(\mathrm{C}-\mathrm{H}$, $\left.2931 \mathrm{~cm}^{-1}\right)$, stretching carbonyl esters deformation $(\mathrm{C}=\mathrm{O}$, $\left.1741 \mathrm{~cm}^{-1}\right)$, aromatic rings absorption band $(\mathrm{C}=\mathrm{C}, 1606$ and $\left.1512 \mathrm{~cm}^{-1}\right)$ and oxygen carbon stretching vibrations with single bonds $\left(\mathrm{C}-\mathrm{O}, 1190 \mathrm{~cm}^{-1}\right)$. It was possible to observe the acid carbonyls $\left(\mathrm{C}=\mathrm{O}, 1720 \mathrm{~cm}^{-1}\right)$ indicating that occurred partial hydrolysis from the triacylglycerides.

The ${ }^{1} \mathrm{H}$ NMR spectrum for safflower seed oil and PSO is shown in Figure 2. Thus, it is observed that there was partial addition of hydroquinone to the safflower seed oil, as there are signs of aromatics hydrogens (around $6.76 \mathrm{ppm}$ ), as well as signs of methine hydrogen (HC-Ph; 2.99 ppm). The chemical structure of the PSO is shown in Figure 3.

Figure 4 shows the effect of PSO on the oxidative stability of biodiesel, the synthesized additive was shown to be compatible with biodiesel at all concentrations used. Biodiesel without the additive present $8 \mathrm{~h}$ of oxidative

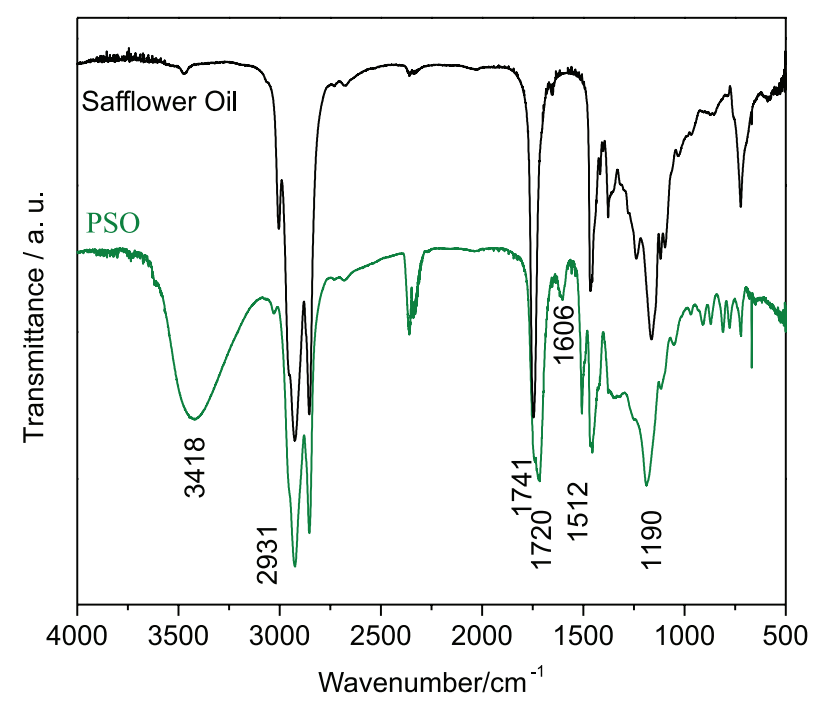

Figure 1. FTIR-ATR of the safflower seed oil and PSO.

stability, in agreement with Pereira et al. ${ }^{45}$ findings. However, the oxidative stability of the mixture of soybean biodiesel and tallow biodiesel (commercial biodiesel) has a lower result than that specified by ANP, ${ }^{46}$ which is currently at least $12 \mathrm{~h}$. Therefore, the addition of additives is necessary. The PSO presented, in the concentrations of 1000, 2000, and 5000 ppm, 12, 13 and $17 \mathrm{~h}$ of the induction

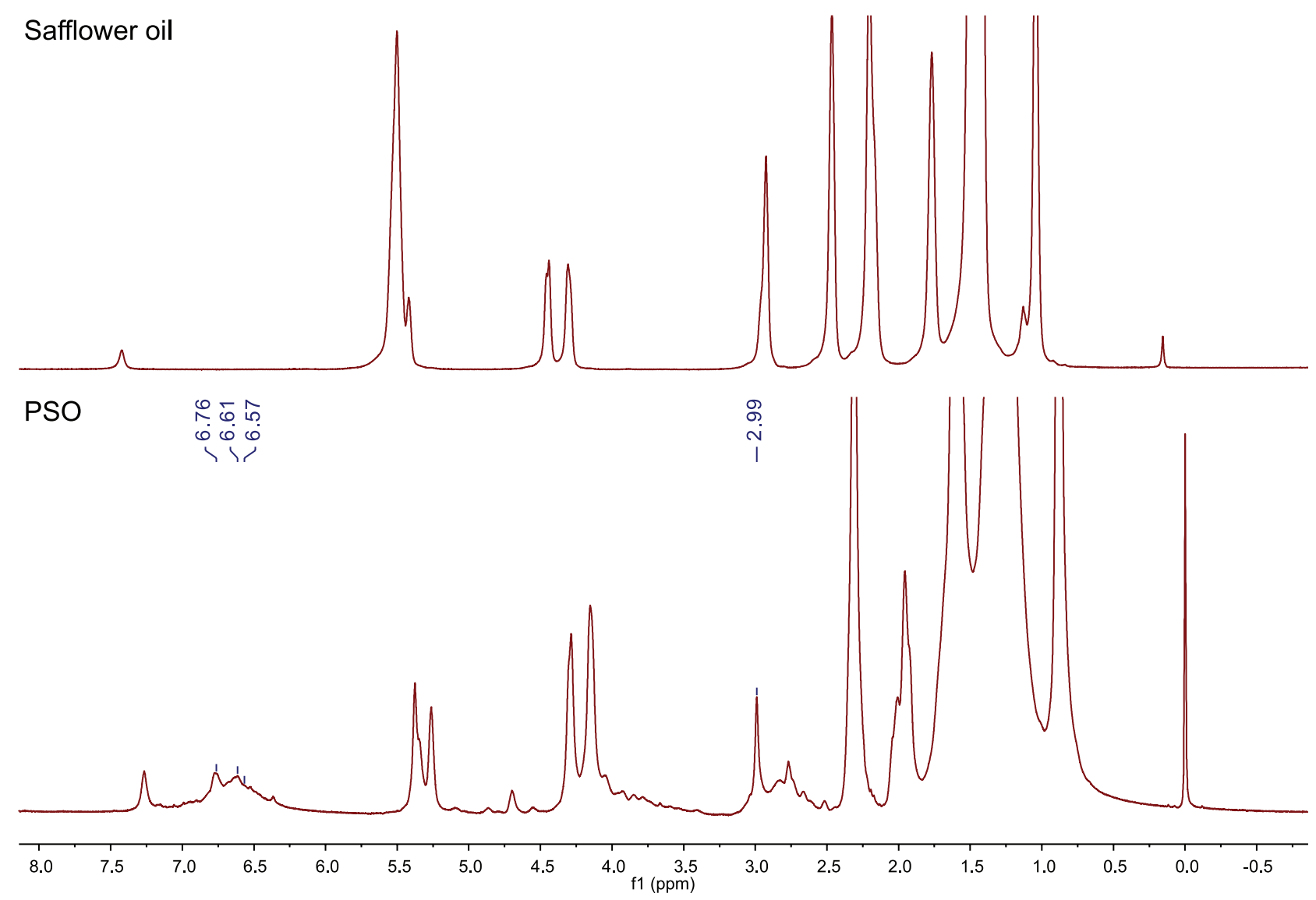

Figure 2. ${ }^{1} \mathrm{H}$ NMR $\left(500 \mathrm{MHz}, \mathrm{CDCl}_{3}\right)$ spectrum of the safflower seed oil and PSO. 


\section{PSO}<smiles>CCCCC(C)CCCCCCCC(=O)OC[C@@H](COC(=O)CCCCCC(C)(C)CCCC)OC(=O)CCCCCC(C)(C)CCCC</smiles>

Figure 3. Structure of PSO.

period, respectively. Thus, it is possible to conclude that in concentrations from 1000 ppm PSO can be used as an antioxidant additive in commercial biodiesel, as it meets the ANP requirement. ${ }^{46}$

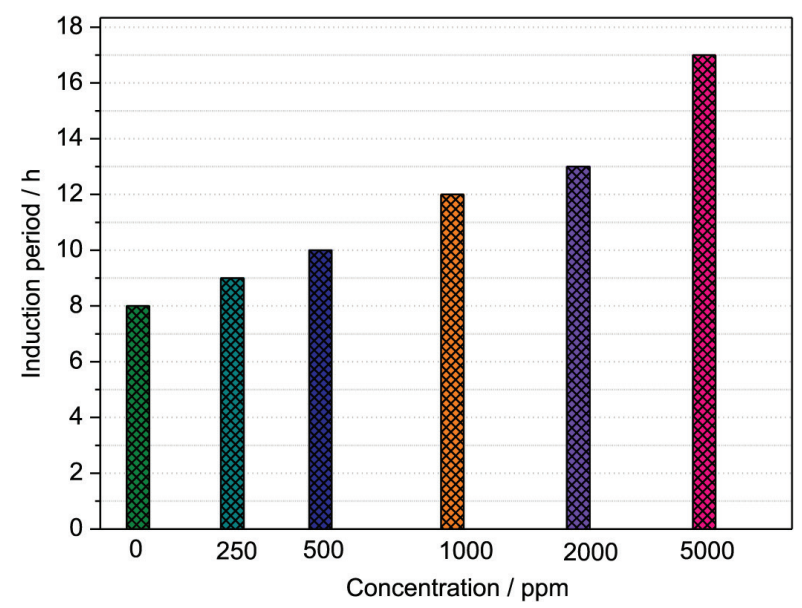

Figure 4. Effect of antioxidants on oxidative stability of biodiesel.

The synthesized additive was easily soluble in commercial biodiesel. The immobilization of hydroquinone in the unsaturated chains of safflower seed oil causes the increase in the solubility of the phenolic compound in biodiesel favoring the antioxidant action, thus the additive is soluble in commercial biodiesel at different concentrations. The product synthesized herein can be used to protect the biodiesel oxidation inhibiting the degradation processes by improving the oxidative stability of it, mainly because hydroxyls could decrease the formation and propagation of chain free radicals by providing active protons capable of inhibiting and retarding the oxidation rate of biodiesel. ${ }^{13,33}$

\section{Conclusions}

The additive herein synthesized was obtained using methanesulfonic acid as a catalyst via electrophilic substitution reaction linking hydroquinone on a double bond present in the safflower seed oil. The product obtained in this research was evaluated as an antioxidant in commercial biodiesel using the Rancimat method, providing promising results, getting up parameters established by standard ANP (12 h), in concentration as $1000 \mathrm{ppm}$.

The immobilization of hydroquinone in the unsaturated chains of safflower seed oil increases the solubility of the phenolic compound in biodiesel favoring the antioxidant action, thus the additive is soluble in commercial biodiesel at different concentrations. Thus, using 5000 ppm of additive, the induction period increased from 8 to $17 \mathrm{~h}$ (2.12 times).

As the oil derived from safflower seed has some limitations to be used as biodiesel, this study aimed to develop an antioxidant additive for biodiesel, using safflower seed oil. Thus, this research brought a positive response to the improvement of oxidation stability of biodiesel through the use of the synthesized additive, which creates a possibility to increase the use and expansion of this fuel in the market, such as the use of safflower seed as a raw material for additives, bringing a new market for these seeds.

\section{Acknowledgments}

The authors are grateful to FUNAPE, FINEP, CNPq for financial support and CAPES for the scholarship to Maríthiza G. Vieira and Lilian R. Batista. The authors are grateful to the Departamento de Botânica, Ecologia e Zoologia of UFRN, especially Juliana E. Lichston for the supply of safflower seeds and to the Laboratorio de Ressonância Magnética Nuclear (LabRMN) of UFG.

\section{Author Contributions}

Maríthiza G. Vieira was responsible for data curation, investigation, formal analysis, writing original draft, writing review and editing; Lilian R. Batista for the investigation, conceptualization and writing original draft; Aline S. Muniz for the conceptualization, methodology, writing original draft; Juliana E. for the resources; Angelo R. S. Oliveira and Maria A. F. César-Oliveira for the methodology and Nelson R. A. Filho for the resources project administration and funding acquisition. 


\section{References}

1. Hall, C. In Encyclopedia of Food Grains, vol. 4, $2^{\text {nd }}$ ed.; Wrigley, C. W.; Corke, H.; Seetharaman K.; Faubion, J., eds.; Elsevier: Waltham, 2016, p. 254-258.

2. Mihaela, P.; Josef, R.; Monica, N.; Rudolf, Z.; Fuel 2013, 111, 114.

3. Thoai, D. N.; Kumar, A.; Prasertsit, K.; Tongurai, C.; Energy Procedia 2017, 138, 544.

4. Khalid, N.; Khan, R. S.; Hussain, M. I.; Farooq, M.; Ahmad, A.; Ahmed, I.; Trends Food Sci. Technol. 2017, 66, 176.

5. Yeilaghi, H.; Arzani, A.; Ghaderian, M.; Fotovat, R.; Feizi, M.; Pourdad, S. S.; Food Chem. 2012, 130, 618.

6. Soleymani, A.; Ind. Crops Prod. 2019, 131, 378.

7. Yesilyurt, M. K.; Cesur, C.; Aslan, V.; Yilbasi, Z.; Renewable Sustainable Energy Rev. 2020, 119, 109574.

8. Zhou, X.; Tang, L.; Xu, Y.; Zhou, G.; Wang, Z.; J. Ethnopharmacol. 2014, 151, 27.

9. Bessada, S. M. F.; Barreira, J. C. M.; Oliveira, M. B. P. P.; Ind. Crops Prod. 2015, 76, 604.

10. Ilkılıç, C.; Aydın, S.; Behcet, R.; Aydin, H.; Fuel Process. Technol. 2011, 92, 356.

11. Khounani, Z.; Nazemi, F.; Shafiei, M.; Aghbashlo, M.; Tabatabaei, M.; Energy Convers. Manage. 2019, 201, 112184.

12. de Oliveira, C. V. K.; Santos, R. F.; Siqueira, J. A. C.; Bariccatti, R. A.; Lenz, N. B. G.; Cruz, G. S.; Tokura, L. K.; Klajn, F. F.; Ind. Crops Prod. 2018, 123, 192.

13. Muniz-Wypych, A. S.; da Costa, M. M.; Oliveira, A. R. S.; Neu, P. M.; Schober, S.; Mittelbach, M.; Ramos, L. P.; César-Oliveira, M. A. F.; Eur. J. Lipid Sci. Technol. 2017, 119, 1700179.

14. Saluja, R. K.; Kumar, V.; Sham, R.; Renewable Sustainable Energy Rev. 2016, 62, 866.

15. Varatharajan, K.; Pushparani, D. S.; Renewable Sustainable Energy Rev. 2018, 82, 2017.

16. Medeiros, M. L.; Cordeiro, A. M. M. T.; Queiroz, N.; Soledade, L. E. B.; Souza, A. L.; Souza, A. G.; Energy Fuels 2014, 28, 1074.

17. Ramos, L. P.; Kothe, V.; César-Oliveira, M. A. F.; MunizWypych, A. S.; Nakagaki, S.; Krieger, N.; Wypych, F.; Cordeiro, C. S.; Rev. Virtual Quim. 2017, 9, 317.

18. Ramalingam, S.; Rajendran, S.; Ganesan, P.; Govindasamy, M.; Renewable Sustainable Energy Rev. 2018, 81, 775.

19. Agarwal, S.; Singhal, S.; Singh, M.; Arora, S.; Tanwer, M.; ACS Sustainable Chem. Eng. 2018, 6, 11036.

20. de Sousa, L. S.; de Moura, C. V. R.; de Oliveira, J. E.; de Moura, E. M.; Fuel 2014, 134, 420.

21. Santos, N. A.; Damasceno, S. S.; de Araújo, P. H. M.; Marques, V. C.; Rosenhaim, R.; Fernandes, V. J.; Queiroz, N.; Santos, I. M. G.; Maia, A. S.; Souza, A. G.; Energy Fuels 2011, 25, 4190.

22. França, F. R. M.; dos Santos Freitas, L.; Ramos, A. L. D.; da Silva, G. F.; Brandão, S. T.; Fuel 2017, 203, 627.
23. Bharti, R.; Singh, B.; Fuel 2020, 262, 116658.

24. Kumar, N.; Fuel 2017, 190, 328.

25. Sarin, A.; Singh, N. P.; Sarin, R.; Malhotra, R. K.; Energy 2010 , 35,4645 .

26. Nivetha, S.; Roy, D. V.; J. Energy Chem. 2013, 22, 935.

27. Joshi, G.; Lamba, B. Y.; Rawat, D. S.; Mallick, S.; Murthy, K. S. R.; Ind. Eng. Chem. Res. 2013, 52, 7586.

28. Zhou, J.; Xiong, Y.; Shi, Y.; Energy Fuels 2016, 30, 10534.

29. Alberici, R. M.; Simas, R. C.; Abdelnur, P. V.; Eberlin, M. N.; de Souza, V.; de Sá, G. F.; Daroda, R. J.; Energy Fuels 2010, 24,6522 .

30. Karavalakis, G.; Stournas, S.; Energy Fuels 2010, 24, 3682.

31. Hosseinzadeh-Bandbafha, H.; Tabatabaei, M.; Aghbashlo, M.; Khanali, M.; Demirbas, A.; Energy Convers. Manage. 2018, 174,579 .

32. Ohkatsu, Y.; Nishiyama, T.; Polym. Degrad. Stab. 2000, 67, 313.

33. ABNT NBR 14065: Destilados de Petróleo e Óleos Viscosos Determinação da Massa Específica e da Densidade Relativa pelo Densímetro Digital, ABNT: Rio de Janeiro, 2013.

34. ABNT NBR 10441: Produtos de Petróleo-Líquidos Transparentes e Opacos-Determinação da Viscosidade Cinemática e Cálculo da Viscosidade Dinâmica, ABNT: Rio de Janeiro, 2014.

35. EN 14112: Fat and Oil Derivatives, Fatty Acid Methyl Esters (FAME), Determination of Oxidation Stability (Accelerated Oxidation Test), European Committee for Standardization: Berlin, 2016.

36. ABNT 14483: Produtos de Petróleo-Determinação da CorMétodo do Colorímetro ASTM, ABNT: Rio de Janeiro, 2015.

37. ASTM D 2500: Standard Test Method for Cloud Point of Petroleum Products and Liquid Fuels, ASTM International: West Conshohocken, PA, 2017.

38. ASTM D 97: Standard Test Method for Pour Point of Petroleum Products, ASTM International, West Conshohocken, PA, 2017.

39. Hartman, L.; Lago, R. C. A.; Lab. Pract. 1973, 22, 474; Menezes, R. S.; Leles, M. I. G.; Soares, A. T.; Franco, P. I. B. M.; Antoniosi Filho, N. R.; Sant'Anna, C. L.; Vieira, A. A. H.; Quim. Nova 2013, 36, 10.

40. Singh, D.; Sharma, D.; Soni, S. L.; Sharma, S.; Kumari, D.; Fuel 2019, 253, 60.

41. Issariyakul, T.; Dalai, A. K.; Renew. Sustain. Energy Rev. 2014, $31,446$.

42. Sajjadi, B.; Raman, A. A. A.; Arandiyan, H.; Renewable Sustainable Energy Rev. 2016, 63, 62.

43. Yaakob, Z.; Narayanan, B. N.; Padikkaparambil, S.; Unni K., S.; Akbar P., M.; Renewable Sustainable Energy Rev. 2014, 35, 136.

44. Bondet, V.; Brand-Williams, W.; Berset, C.; LWT - Food Sci. Technol. 1997, 30, 609.

45. Pereira, G. G.; Garcia, R. K. A.; Ferreira, L. L.; BarreraArellano, D.; J. Am. Oil Chem. Soc. 2017, 94, 587. 
46. Agência Nacional do Petróleo, Gás Natural e Biocombustíveis (ANP); Resolução ANP No. 45, Dispõe sobre a Especificação do Biodiesel Contida no Regulamento Técnico ANP No. 3 de 2014 e as Obrigações quanto ao Controle da Qualidade a Serem Atendidas pelos Diversos Agentes Econômicos que
Comercializam o Produto em Todo o Território Nacional; Diário Oficial da União (DOU), Brasília, de 26/08/2014.

Submitted: April 6, 2020

Published online: July 27, 2020 